\title{
Albert the Great, the Albert Legend, and the Legitimation of the Dominicans
}

\author{
Scott E. Hendrix
}

check for

updates

Citation: Hendrix, Scott E.. 2021. Albert the Great, the Albert Legend, and the Legitimation of the Dominicans. Religions 12: 992. https://doi.org/10.3390/rel12110992

Academic Editor: Marina Montesano

Received: 14 September 2021

Accepted: 8 November 2021

Published: 12 November 2021

Publisher's Note: MDPI stays neutral with regard to jurisdictional claims in published maps and institutional affiliations.

Copyright: (C) 2021 by the author. Licensee MDPI, Basel, Switzerland. This article is an open access article distributed under the terms and conditions of the Creative Commons Attribution (CC BY) license (https:// creativecommons.org/licenses/by/ $4.0 /)$.
Department of History, Political Science, and Religious Studies, Carroll University, Waukesha, WI 53186, USA; shendrix@carrollu.edu

\begin{abstract}
By the time of his death in 1280 Albert the Great was respected not only as a theologian and philosopher, but also as one of the greatest authorities on astrology in the West. Such expertise rarely gains plaudits today, but in late medieval Europe knowledge of esoteric pursuits was held in high regard. This is why Dominicans not only did nothing to challenge the growth of the "Albert Legend," that Albert had mastered all magical and esoteric topics, but also promoted this myth. By promoting this legend, they bolstered and legitimized the reputation of the Order of Preachers.
\end{abstract}

Keywords: Albert the Great; Albertus Magnus; astrology; magic The Book of Secrets; Order of Preachers; Speculum astronomiae; the Albert Legend

\section{Introduction}

In the thirteenth and fourteenth centuries, the Order of Preachers-the Dominicanswas a new organization, emerging from the intellectual and institutional froth that was the thirteenth century, and as such had a need for legitimation both against venerable rivals such as Benedictines and equally youthful upstarts such as the Franciscans. Since Dominic de Guzman founded the order with an inbuilt interest in education and scholarship from its inception, it was only natural that strategies of legitimation would push against the cutting edges of intellectual activity. For the thirteenth century this was not only the Aristotelianism that was becoming the core of all formalized academic study, but the "astrologizing Aristotelianism" that tied the mathematical disciplines providing the basis of the quadrivium together. ${ }^{1}$ Thus, in the thirteenth century astrology was not the fringe discipline it is today-it was linked directly to interest in Aristotle, and no one in Christendom was a more authoritative name when it came to the reception of astrology than Albertus Magnus. However, as Dominicans promoted Albert as the expert on astrology, or at least the ways in which astrology was congruent with Catholic belief, his reputation soon began to be invoked as an expert on all things magical and esoteric, from alchemy to outright wizardry, for all these disciplines were intimately interlinked to astrology (Copenhaver 1988, pp. 264-300). Albert's name became one to conjure with in a quite literal sense, and though this was at first useful as a tool of legitimation for the Dominicans, it eventually came to be something of an embarrassment that slowed Albert's path to canonization for centuries.

From the moment of the order's founding in 1216, Dominic emphasized the need for well-educated preachers who could both counsel their flock and guide them through the crafting of doctrinally sound and rhetorically engaging sermons (Mulchahey 1998, pp. 53-55). However, this earliest conception of Dominican education was intensely conservative, forbidding friars from studying "the books of the pagans and of the philosophers ... the secular sciences nor even the arts which they call liberal" (Mulchahey 1998, pp. 55-56). However, these prohibitions were more reflective of a desire to demonstrate the orthodoxy of this new order and its place within long-established traditions than any directed opposition to the Aristotelianism that was already washing over the universities and the schools of Europe. ${ }^{2}$ Whatever Dominic had intended, though, it would prove impossible to 
resist the "rains of the Aristotelian storm," to borrow Michèle Mulchahey's poetic phrasing (Mulchahey 1998, p. 54). Popes Honorius III (1216-1227) and Gregory IX (1227-1241) rapidly seized on the Dominicans as the mechanism by which they could make Lateran IV's dream of a school of theology in every diocese a reality (Mulchahey 1998, p. 51). During the thirteenth century, despite conservative opposition such as that expressed by bans on the teaching of Aristotle promulgated at the Synod of Sens in 1210 and by the papal legate Robert de Courçon in 1215, Aristotelian philosophy became established as foundational to anyone studying theology (Mulchahey 1998, p. 56).

While Aristotle wrote about many useful things, his empiricist approach meant that he privileged natural philosophy, which had intrigued Albertus Magnus almost from the time he took up serious study after beginning his novitiate in 1223. After the Master General of the order, John Wildeshausen (c.1180-1252), sent him to his old alma mater of Paris to study in 1242, Albert embraced Aristotelian natural philosophy with the fervor of a convert (Hendrix 2010, pp. 53-55). Very quickly he was using Aristotle's system in ways that may have surprised contemporaries - such as in his analysis of the Incarnation and Resurrection of Christ $^{3}$ - but it was his discussion of esoteric subjects that seems to most discomfit modern people while having been the central element of the growth of the Albert legend that initially elevated then later dashed the real Albert's reputation.

As far as Albert was concerned, astrology was foremost among these esoteric subjects. By astrology, here I mean the study of both the presumed influence of the heavens upon terrestrial creatures and events, and a consideration of how such knowledge might be used to gain knowledge or foreknowledge about events on the earth, and even how such influences might be manipulated to our benefit. ${ }^{4}$ Albert's interest derived from his fascination with Aristotelian philosophy, which committed him to careful observation of the world, combining first-hand knowledge with an application of the best philosophical principles available, in order to understand the world as it existed in reality, not in some idealized Platonic form (Kibre 1984, p. 195; Parker 1980, pp. 158-59). For Albert, as with many other medieval thinkers, the cosmos was God's divinely ordered machine and any analysis of creation must focus upon the world as it exists, in all its constituent parts (North 1995, p. 265). Within this cosmological view, the world sits within a cosmic web of power originating with God, flowing through each level of creation, down to the terrestrial realm. This heavily Neoplatonic notion infuses all of Albert's thought, influenced by his mistaken belief that the Liber de causis was either a section of Aristotle's Metaphysics or the work of the Jewish philosopher Abraham Ibn Daud (c.1110-1180), ${ }^{5}$ rather than a paraphrasing of ideas drawn from Proclus and Avicebron (de Libera 1990, pp. 55-59). Abraham ibn Daud, who Albert also refers to as Avendaud, may have written a nowlost Metaphysics, drawing from sources including al-Fārābī (d. 950), Ibn Sīnā (980-1037), and al-Ghazālī (1058-1111), as he did in his Exalted Faith (Szilágyi 2016, p. 28). If Albert was familiar with a now-lost work on Metaphysics by ibn Daud, as Szilágyi has argued, Albert would have found the Jewish scholar's blending of Aristotelian and Neoplatonic approaches quite congenial, given his own similar approach. Influenced either by his mistaken belief that the Liber de causis was a section of Aristotle's metaphysics, or by the work of Abraham ibn Daud, Albert's cosmological views contained significant Neoplatonic elements, including a belief that each of the celestial orbs affected the downward flow of divine power, making it not only possible but also of paramount importance to understand the impact of these influences on the human body and human actions (de Libera 1990, pp. 116-18). The importance Albert placed on understanding these celestial effects is why astrology entered into his writings almost every time he put pen to paper, from his earliest extant work, De bono, to his latest work, an uncompleted Summa theologiae (Thorndike 1923, pp. 584, 589).

It was this intense and prolonged interest in astrology that made this discipline so central to the Albert legend, the glorification of Albert that placed him on a level of expertise almost with Aristotle (Hackett 2013, p. 443). Albert's fellow Dominicans laid the foundations for this legend during Albert's own lifetime, with Ulrich of Strasbourg describing 
Albert as "a man so superior in every science, that he can fittingly be called the wonder and miracle of our time," then singling out the esoteric disciplines, noting that the elder Dominican was "experienced in magic." ${ }^{6}$ Ulrich may have been misled by a line Albert writes about Hermeticism in his De anima, in which he states "I myself am experienced in magic," ${ }^{\prime 7}$ but his assertions are also suggestive that he may have been exaggerating Albert's range of expertise in order to enhance the reputation of the Dominican order. After all, interest in learned magic was on the rise in the thirteenth century (Bailey 2007, pp. 108-18). However, astrology was foundational to learned magic and it was in questions involving this discipline that Albert's name would be most regularly invoked in the thirteenth century. For example, Dominicans were quick to ask Albert for his thoughts on the subject when controversy exploded at the University of Paris in the 1270s over issues directly tied to Aristotelian philosophy and questions revolving around astrology (Hissette 1977). Giles of Lessines (c.1235-c.1305)—who was studying under Thomas Aquinas at the time-wrote his professor's old master to ask his thoughts on fifteen questions related to the controversy, four of which touched directly on astrological doctrines. ${ }^{8}$ It is unclear how important Albert's rather cranky and direct answers were to the debates following the Parisian Condemnations of 1270 and 1277, but what is clear is that Albert's reputation as an authority on the relationship between astrology and theology was already very high. It is likely that the Dominicans sought to capitalize on this reputation in the thirteenth century, as it served to burnish the reputation of the order.

\section{The Development of the Albert Legend}

Albert's reputation as an expert on both astrology and other forms of natural philosophy led to his name becoming associated with one of the most popular medical works of the Middle Ages, De Secretis Mulierum. Composed sometime in the late thirteenth or early fourteenth century by one of Albert's students, this book was widely thought to be a genuinely Albertine work until the early twentieth century when Lynn Thorndike demonstrated that the author differed greatly from Albert's style on numerous key points (Thorndike 1955, pp. 413-43). The existence of eighty-three surviving manuscripts of this work makes it something of a medieval bestseller, aided by the prestige lent by the medieval attribution of this work to Albert. Readers accepted this attribution for so long because the author followed Albert in his discussion of the role of celestial influence on a developing fetus, the fate of people conceived and born under certain celestial configurations, and philosophical and theological questions raised by the belief that the heavens incline us toward certain personalities, actions, and so forth in our life (Lemay 1992, pp. 1-2). ${ }^{9}$ These considerations about fate are only incidental to the De secretis, though, with far more attention paid to questions about conception, gynecology, and treatments that frequently borrow from traditions of folk or learned magic. While a modern scholar can clearly see that this is a work that occasionally incorporates Albertine ideas, even though Albert was certainly not its author, it took many centuries for anyone to perform the close reading and textual analysis necessary to demonstrate that conclusively. Therefore, just as with other works of the late thirteenth and early fourteenth centuries such as the De alchimia or De mirabilibus mundi, there was a flourishing tradition of assigning Albert as the author to esoteric works, which worked in favor of the reputation of both Albert and his order in this period. Thus, the Dominicans may well have encouraged the attribution of such works to Albert, who was a shining star of their order. At the very least, they did nothing to discourage assigning authorship of these esoteric works to Albert.

The strength of Albert's reputation as an expert on esoteric subjects would only grow in centuries to come, even expanding into areas where he wrote little or nothing, and the Dominicans were not shy about appealing to that reputation to legitimate their order. It became particularly important that they have such an authority to which they could appeal as interest in learned magic, alchemy, and astrology only increased in the fourteenth and fifteenth centuries, creating a motivation to tie the Dominicans to one of the strongest intellectual trends of the late medieval and Renaissance periods. ${ }^{10}$ However, 
just as importantly the Dominicans would need to be able to distance themselves, and illustrious forebears such as Albert, from any illicit forms of esoterica, as suspicion of magic and esoteric topics grew concurrently with positive interest in these fields.

Despite the survival of magical tracts such as John of Morigny's Liber florum coelestis doctrine, practitioners of learned magic during the fourteenth century tended to maintain a low profile (Fanger and Watson 2015, introduction). These practitioners tended to live in quiet groups of like-minded people in locations such as the abbey of St. Augustine's in Canterbury, where monks practiced magic in order to fulfill personal needs (Page 2013, pp. 3-17). Other practitioners worked in isolation, often as chantry priests, where they might practice magic for a variety of reasons, not the least of which was to stave off boredom. ${ }^{11}$ The evidence suggests that the practice of magic was not uncommon among educated monks, priests, and physicians. However, since such practices frequently involved the invocation of spirits or the use of incantations in languages unknown to the magic user, great care had to be taken lest one draw the attention of the newly formed papal inquisition. This was especially true after 1320 when Pope John XXII (r.1316-1334) directed inquisitors in Toulouse and Carcassone to search out necromancers and other magicians due to fears that an individual could commit practical heresy by performing an act constituting heresy without being consciously aware this action was in any way heretical, a concern unknown before the fourteenth century (Kieckhefer 2000, p. 192). For example, a magician might use words in an unknown language in the course of casting a spell, unaware that these phrases represented a demonic invocation. The seriousness with which Pope John XXII viewed this issue cannot be doubted, given the fate of a man in his personal employ, Cecco d'Ascoli, burned at the stake in 1327 on just such charges (Thorndike 1934, p. 35).

However, we should be cautious about interpreting such events as the papal pronouncement of 1320 or the execution of Cecco d'Ascoli in 1327 as a condemnation of magic, broadly speaking. Instead, what fourteenth-century authorities were concerned about was what John XXII termed the "pestilential disease" of summoning and consorting with demons. This was what his decretal Super illius specula attacked, sentencing anyone who "engaged in demonic invocation, offered sacrifices to demons to procure supernatural services, or worshipped demons in any way" to automatic excommunication (Bailey 2006, p. 598). Thus, it was not magic or astrology that drew papal ire, it was the misuse of these disciplines. What was needed was a handbook of some sort to help people interested in occult arts avoid being burned at the stake.

Fortunately, one such handbook was readily available, the work commonly known as the Speculum astronomiae. ${ }^{12}$ While there is dispute over the identity of its author, vanishingly few in the late Middle Ages doubted that Albertus Magnus was the author. I've dealt with that controversy elsewhere (Hendrix 2018), but whether or not Albert was the actual author of the Speculum is largely irrelevant to the current project. For as Massimo Rondolino has argued "the hagiographical process, as a particular form of dynamics of legitimation, is the phenomenon by which members of given religious communities ... configure their present identity," through the construction and reconstruction of their past (Rondolino 2017, pp. 16-17). Thus, what matters is that Dominicans and others accepted Albert as the author of the Speculum and used this work in a variety of ways to defend Albert and legitimize their order. For this purpose, the Speculum was perfect, as it was written so that the "licit may be separated from the illicit," allowing readers to avoid astrological practices-including those involving magic - that might lead one into heresy (Albert the Great 1992, p. 208).

The importance of growing concerns about heresy and the development of a belief that heresy could manifest itself unintentionally to our present study is to be found in the connections between astrology and magic existing in the minds of medieval scholars (Kieckhefer 2000, p. 190). Astrology was foundational to the practice of magic, ${ }^{13}$ creating a need to assure others that those interested in astrology and magic were interested only in the non-heretical forms (Levack 1995, pp. 7, 38; Schwartz 2005). The Speculum was very useful for this purpose, as we can see with Pierre d'Ailly (1351-1420) in his Vigintiloquium 
de concordantia astronomicae veritatis cum theologia. Writing at Cologne in 1414, he refers to the Speculum when he states:

Albert the Great produced a useful tract, in which he distinguished books of true astronomy and of the art of magic by their principles and boundaries, so that he might distinguish true astronomy and empty magic from one another. ${ }^{14}$

Clearly d'Ailly saw the Speculum as a guide to avoiding illicit works of magic. With the association between magic and astrology that existed, and the growing suspicion toward magic evidenced both by papal pronouncements and the sharp rise of prosecutions associated with a shift from accusatorial to inquisitorial procedure, we can certainly see why astrologers would want such a guide (Kieckhefer 2000, p. 193).

It is probably the usefulness of the Speculum as a guide to the avoidance of heresy and as an authenticating device to demonstrate one's orthodoxy that caused an explosion in interest in the work during the fourteenth century; ${ }^{15}$ the Speculum handily provided a comprehensive bibliographic guide to both the licit and illicit works on astrology and the related discipline of image magic, which the Speculum seems to have introduced to Europe (Weill-Parot 2002, p. 28). This was a form of magic performed by harnessing celestial power through the use of an object such as a ring with carved sigils of power, a practice common to physicians as a form of medical treatment (Weill-Parot 2002, p. 290). Thus, by consulting the Speculum the astrologer was able to learn both the most important foundational works for the practice of his discipline and avoid reading those "cursed necromantic books" that employ fumigations and demonic invocations while mendaciously taking on the name of astrology in order to "render themselves [as] slightly credible." 16 Furthermore, by including the Speculum in a codex along with other astrological or magical works, it functioned as an instrument to validate the user's position without requiring extensive argumentation, definition of terms, and presentation of evidence. Furthermore, by binding the Speculum with other astrological and magical works, a complex interchange is created in which the Speculum functions to legitimize the astrological works referenced by the authors of the works with which it is bound, while the astrological works mentioned in those works reinforce the legitimacy of the astrological works referenced in the Speculum. Such a legitimizing device functions to convey that the user has comprehensive knowledge of a particular subject while indicating agreement with a set of recognizable arguments represented by the device in question, thus authenticating to anyone who examined the codex that its owner and/or compiler was both knowledgeable and orthodox in his approach to astrology and related disciplines such as magic (Hendrix 2010, pp. 4-7, 44, 96). Furthermore, in terms of long-term importance, the interlocking references to astrological works contained in the Speculum and those works with which it came to be bound served to reinforce which astrological works should be preserved in the future-and which should be allowed to become lost to time.

As a bibliographic guide and authenticating device scholars from a variety of backgrounds, from the early fourteenth-century physician Pietro d'Abano (c.1257-1316) to the fifteenth-century humanist Giovanni Pico della Mirandola (1463-1494), referenced the Speculum in their own work, either in support of their acceptance of the use of astrology or to attack that use (Hendrix 2010, chp. 4). Thus, across Europe the Speculum served to enhance both Albert's reputation and the reputation of the Dominicans, a likely reason for Dominican support of this influential work. This influence grew in the fourteenth century on, when every court in Europe had a resident astrologer (Carey 1987, pp. 53-55), the numbers of academically trained physicians were growing, and the perceived need for their services also grew with the onset of catastrophic events such as the Black Death (Siraisi 1990, p. 68). Additionally, the fourteenth century saw the professionalization of surgeons in regions such as France and Italy, and no university-trained medical professional in the Middle Ages or Renaissance would administer treatment without first consulting the stars (Siraisi 1990, pp. 68-90). The Speculum, then, would have been widely if not universally known and valued among these medical professionals, who often worked as 
astrological advisers as well, which would have spread Albert's fame-and the fame of his order-far beyond the ranks of the religious.

To name one famous example, for Dante Alighieri (1265-1321) Albert was an indispensable source for knowledge about astronomical issues, even if Dante did not always properly acknowledge his source. Though Dante referenced the ninth-century Persian astrologer Albumasar (787-886) in his Convivio when he wrote that the ignition of vapors around the planet Mars is a portent of the death of kings or other major political changes, he was actually drawing directly from Albert's commentary, De meteoris. ${ }^{17}$ Perhaps Dante's most important debt to Albert was in his understanding of free will, drawn directly from Albert's writing on the subject and providing the basis for Dante's ethics (Bianchi 2015, pp. 160-63). Given the widespread fame Dante so quickly gained, his repeated references to Albert-whom he placed alongside his pupil and fellow Dominican Thomas Aquinas among the Spiriti Sapienti in the Heaven of the Sun-could only have enhanced the reputation of the Albert and the Dominicans (Franke 2000, p. 11).

\section{Albert as Magus?}

As broad as Albert's academic interests were, his fame soon transcended the actual scope of his expertise, quickly making inroads into areas of discourse beyond the rarefied realms of intellectuals. During the fourteenth century the perception of Albert as a wizard began to emerge, perhaps based partly on an understanding that Albert was the most important authority on astrology-a discipline that many elites encountered through medical astrology or due to its usefulness for the advice astrologers could provide-and inspired in part by allegorical stories Dominican preachers told about Albert. The most important example of this latter instance is the Bonum Universale de Apibus. Thomas of Cantimpré (1201-1272), a Dominican who studied under Albert at Paris, composed this work between 1256 and 1263, including more than 350 exempla useful for sermons; among these were such gems as Albert requesting that God allow him to visit purgatory so that he might truly learn all things (Collins 2010, p. 17). This work exists in dozens of extant manuscripts and six printed editions done between 1472 and 1627, so it was widely known and used by preachers for centuries (Cohen 2008, p. 17). While stories such as Albert's conversation with God about traveling to purgatory was as allegorical as the various uses of bees, griffons, and other creatures real and imagined included in the Bonum Universale, not all who heard the stories used in sermons would have necessarily understood what the author of the allegory had meant. It was a small step to make from hearing about Albert traveling-or attempting to travel—to purgatory and imagining that he had even greater powers, especially if the listener had heard anything about Albert's associations with astrology, magic, and other esoteric subjects.

This could explain how Matteo Corsini (1322-1402) arrived at his view of Albert as a wonderworker. ${ }^{18}$ Unlike those who would have learned about Albert through their university studies, Matteo was not part of the intellectual elite. Born into a family that had made its wealth in the Florentine wool trade before diversifying into banking, Matteo had been raised by his uncle Tommaso after the early death of his father (Papi 1983, pp. 644-47). After a financial crisis gripped Florence in 1343 and greatly reduced the wealth of the Corsini family, Tommaso sought to diversify its interests by pursuing ecclesiastical and learned professions for the Corsini sons, in addition to branching their wool and banking businesses out by establishing an office in London, where Matteo worked for a time (Papi 1983, p. 645). The important thing for the purposes of this paper is that Tommaso clearly recognized the value of education for the Corsini sons; this is not surprising as this was a time when Florentine merchants normally insured the sons of their family would receive an education through attendance at one of the vernacular schools becoming increasingly common across Italy in the fourteenth century or by hiring a tutor (Black 2006, pp. 93-96). Matteo Corsini would have learned at least basic Latin as well, along with vernacular literacy and numeracy as well as an understanding of the value of education for its role in growing one's social capital from an early period in his life (Black 2007, pp. 47-49, 61-62). 
As he aged, Matteo Corsini never forgot those lessons of his youth. By the 1370s, he had established himself back in Florence and had an eye on advancing himself politically. Having invested in land and married into the Strozzi family-one of the Florentine oligarchic families - in the 1360s he was now ready to establish himself in the highest ranks of society by earning election as consul of the wool guild, a position he would hold six times, and he eventually even gained the title of Count Palatine from the Holy Roman Emperor, Charles IV (r.1346-1378) (Davies 1998, pp. 98-101; Goldthwaite 1980, pp. 273-75). During this time, Matteo was an avid diarist and a friend to Francesco Petrarch (1304-1374), so there is every indication that he understood the value of demonstrating a familiarity with literature in promoting his status.

It was between the Ciompi Revolt of 1378 and 1382, the year the city offered Matteo the rank of equestrian due to his handling of this revolt (Papi 1983, p. 647), that the Corsini family was at its peak power in Florence. It is likely due to this prominence that Matteo made his one and only foray into literary writing. The Rosarium odor vitae is an intriguing little book made up of eighty-four short chapters, each representing a reflection on a given virtue or vice. ${ }^{19}$ Although the language of composition is Italian, the title of each chapter, from chapter one's "virtus" to chapter eighty-four's "mulieris bonae" is in Latin, no doubt so that the author can enhance his respectability as a learned man, a point reinforced by his regular inclusion of Latin quotations drawn from the Bible or classical sources. ${ }^{20}$ While there are many interesting features and exempla contained in the book, the most interesting point for the purposes of this paper is the single reference to Albertus Magnus, contained within chapter II, "Sapientia." Matteo opens this chapter with a slightly modified quote from the "Book of Wisdom," or "Sapientia" as it is known in the Vulgate: "Sapienta speciosior sole, et super omnem dispositionem stellarum: luci comparata, invenitur."21 After including quotes from the book of Isaiah, Seneca, and Socrates-though the latter quote seems to have been taken from Cicero's De natura deorum-Matteo launches into rather bizarre story about Albert:

I could give you infinite examples of how knowledge is revered and honored; but to save words, I will briefly give but one notable example. We find that Albert the Great, of the Order of Preachers, came to such a perfection of mind, that by his great knowledge he made a metal statue for himself by the orbit of the planets, and understood that which it [the statue] said. And it was neither by diabolic arts nor by necromancy: though the great intellects do not delight in them, because it is something to lose the soul and body; and such an art is forbidden by the Christian faith. Hence the statue responded to a friar calling brother Albert, who was not in his cell. This person, believing the statue to be an idol of evil intellect, destroyed it. On the return of Brother Albert, he told him off, and said that he had worked on it for thirty years, and, "I did not learn this science in the Order of Friars." The friar said, "I have acted badly; pardon me. Do you mean that you cannot make another?" Brother Albert responded, "It will not be possible to make another one for thirty-thousand years; until when that planet has made its orbit; and it will not return until that time."22

At first glance, a modern reader might be forgiven for wondering what to do with such a story, yet it's clear that it resonated with audiences of the medieval and Renaissance periods. It was part of a tradition begun by William of Malmesbury, who related that Gerbert of Aurilac, the future Pope Sylvester II (r.999-1003), "after carefully inspecting the stars ... he cast for himself the head of a statue that could speak ... and answer the truth in the affirmative or negative" (Weinryb 2016, p. 159).

Matteo Corsini, then, was not indulging in medieval superstition or just spinning a good yarn. He was placing his work within a tradition that garnered respect, while name dropping Albert in order to affirm to his readers that he, Matteo Corsini, was no coarse wool merchant. Instead, he is a man worthy of respect for his mind. As Weinryb explains, there are five medieval intellectuals associated with talking brazen heads: Gerbert of Aurilac, 
Albertus Magnus, Robert Grosseteste, and Roger Bacon. ${ }^{23}$ For all of these men, their ability to create talking heads represented a perceived command of esoteric knowledge, magic, and astrology. While these may be subjects of derision today, in the fourteenth century they were very much part of the cutting edge of intellectual traditions that would blossom into the Renaissance. In fact, by including the tale of Albert and the brazen head within the Rosarium, Matteo was signaling to his readers that his book was connected to the classical stories of automata going back to the time of the Illiad's reference to Vulcan's self-moving tripods (Marr 2010, pp. 109-10), but the important point here is that Corsini, a wealthy wool merchant rather than an academic, knew the story of Albert creating a brazen head. Furthermore, it is clear that he expected his readers to know enough of Albert to be able to understand the story and its context and to be impressed that Corsini was learned enough to know this story about Albert. Clearly Albert's reputation was widespread if men such as Matteo Corsini knew of him as a master of esoteric arts, which would only have helped the reputation of the Dominicans as the Renaissance emerged in Europe.

However, the Rosarium isn't the only evidence that Albert's reputation as an occult master had spread beyond the ranks of intellectuals. Sometime in the fourteenth century an unknown author composed the vernacular poem, "Es war ein Kung in Frankreich," which contains a rollicking tale of Albert as a youthful student in Paris using magic to seduce a royal princess nightly (Collins 2010, pp. 17-18). The king orders the city whitewashed and the princess employs red paint so that she leaves a trail when summoned forth by magic, allowing the authorities to catch Albert in the act. However, the wily Dominican uses a magic ball of yarn to escape. Remorseful, Albert patches things up with the king-we're not told what the princess thought about this turn of events—and gives up his sinful ways to become the bishop of Regensburg. In what is likely a later addition to the poem, the reader learns that the moral of the poem is that even the most sinful can receive forgiveness through contrition and sacramental confession.

It would be easy to write this poem off, but that would be a mistake. It is likely that the unknown author knew he was relating a completely fictional event, but the fact that he chose to use Albert as the wizard in his poem tells us that Albert's reputation as a master of esoteric arts had become widely disseminated within society. With Matteo Corsini and the unknown author of "Es war ein Kung" writing in the vernacular, we have evidence that in both Italian and German-speaking areas Albert's reputation for expertise in astrology and magic had gone past the bounds of academics. ${ }^{24}$ It seems that this reputation had been fostered by Dominicans such as Thomas of Cantimpré because of the excitement such studies generated in the late medieval and Renaissance periods. However, promoting Albert's reputation in this way as a Dominican legitimation strategy had its risks.

\section{Apocalypticism, Albert, and the Speculum astronomiae and Legitimation}

As the fourteenth century wore on, the fear of necromancy grew apace with the disasters Christendom faced. Not only did death stalk the land due to recurrent bouts of the plague, but the Church was in disarray. Although there were good arguments to be made for moving its center from Rome to Avignon (1309-1377), and the seven successive popes who reigned there were more dedicated and talented than many had once assumed, there is no doubt that for many the papacy now looked like an adjunct of the French crown (Rollo-Koster 2015, pp. 32-60, 130-37). As the Avignonese papacy stumbled into the Great Schism (1378-1417), many people experienced tremendous angst, which promoted a general desire for reform both within the Church and within Christendom at large (Bailey 2003, pp. 54-56). For some, such as the Valencian Dominican friar Vincent Ferrer (1350-1419), who in 1398 reported he'd had a vision of the Last Judgment, the end of the world was truly nigh (McGinn 1998, pp. 253-58). Others, however, found his twenty-year preaching mission deeply alarming and sought an alternative to such panic-inducing views of the world.

One such man was Pierre d'Ailly (c.1350-c.1420). As Laura Ackerman Smoller has detailed, skepticism of astrology in d'Ailly's early work eventually transformed itself to an 
interest in celestial divination as a tool to predict the end times, providing an alternative to the proliferation of uncontrolled prophets such as Ferrer who arose during the Great Schism. (Smoller 1994, chps. 3 and 5). Writing between 1410 and 1414, d'Ailly cast aside all concerns that appeals to celestial divination might lead Christians astray and instead embraced it as a means to understand the crisis affecting the Church and the coming of the possible end of time (Smoller 1994, pp. 57-60). He acknowledges that some demonstrate a problematic and uncritical acceptance of astrology, but d'Ailly states:

I agree, then, with Albert, who was the great professor of Saint Thomas, in that [view of astrology], especially in his own tract, which is called the Speculum, where he deals with this material fully and usefully. ${ }^{25}$

D'Ailly made this statement in a short letter written to his former student, Jean Gerson (1363-1429), who was Chancellor of Paris at that time, in an effort to convince him that astrology was a valid discipline for Christians. In his longer Vigintiloquium de concordantia astronomicae veritatis cum theologia he elaborated a bit on exactly why he found the Speculum to be so useful:

Albertus Magnus wrote a very useful tract, in which he distinguished the books of true astrology and of the magical art by their beginnings and ends, so that he might separate true astrology and useless magic one from another. ${ }^{26}$

Thus, simply by referencing the Speculum, d'Ailly was authenticating both his knowledge of astrology and his orthodoxy, but of more immediate importance for this study was the way in which this man who was one of the most important intellectuals of the late fourteenth and early fifteenth century referenced Albert as an authority on astrology and magic in order to validate his own astrological interests. Pierre d'Ailly became the Chancellor of the University of Paris in 1389 in addition to holding the post of Confessor to King Charles VI (1380-1422), before surrendering these duties in exchange for the bishopric of Le Puy in 1395 (Smoller 1994). In 1397 he was named Bishop of Cambrai before eventually rising to the rank of Cardinal in 1411, and he was one of the leading theologians at the Councils of Pisa (1409) and Constance (1414-1417), the latter of which ended the Great Schism of the Church.

It should come as no surprise, given d'Ailly's efforts to convince his former student Jean Gerson of the validity and usefulness of astrology to Christians, that Gerson would also write about the discipline. Like his mentor, Gerson's life was influential in both the arenas of scholarship and politics (Glorieux 1951, pp. 149-92). Even before he earned his doctorate in theology in 1392, Gerson found himself embroiled in important religious debates with deep political repercussions-most notably acting in 1387 as prosecutor before Pope Clement VII in the University of Paris' attempt to quash the doctrine of the immaculate conception of Mary. Attaining the chancellorship of the University of Paris in 1395 at the age of thirty-two, he held that post until political difficulties he encountered during his involvement in the Council of Constance led him to retire from active life in 1419.

Unlike his mentor, Gerson argued that after the birth of Christ it became impossible to predict future events. The new order that Christ ushered in was one in which the actions of humankind, based as they are on free will, were so varied and unpredictable that it is beyond human capacity to foresee what may come to pass with any measurable degree of accuracy, therefore negating the standing of astrology as an ars. ${ }^{27}$ Furthermore, Gerson had a distinctly suspicious attitude toward the study of astrology in its various forms, due to fears that it had become contaminated with so many superstitions since the time of the patriarchs that its study threatened to drag the soul of anyone so unwise as to undertake it down into eternal darkness. ${ }^{28}$ For these reasons, Gerson took Albert's Speculum to task in his Tricelogium, though in a manner that indicated a strong measure of respect for the venerable Dominican. He stated that

Albert the Great composed a little work upon this matter (astrology) that is called the Speculum of Albert, explaining the manner in which in his own times 
some wished to destroy those books of Albumasar and certain others. It seems, however, that, while preserving the honor of such a learned man, in expounding upon the books of philosophy, especially of the Peripatatics, he applied too much care, greater than benefitted a doctor of the Christians, [although] with nothing about the piety of the faith having been added; thus also in approbation of certain of the books of astrology, especially about images, nativities, sculptures of stones, characters, interrogations, he leaned too much toward the part of superstitions lacking in reason. ${ }^{29}$

We should take particular note of Gerson's mixed view of Albert. Given Gerson's immense standing and importance, referring to Albert as "a learned man" certainly did not hurt either Albert's reputation, or that of his order. However, saying that he "leaned too much toward the part of superstitions lacking in reason" spelled trouble for Albert that eventually his order would not be able to ignore.

Gerson was writing at the beginning of the fourteenth century, but by the second half of the century the sort of suspicions he had about magic were becoming more widespread. Physicians such as Marsilio Ficino (1433-1499) continued to be supporters of magic, advocating the use of astrological images and other magical forms of medical treatment (Allen 1941, p. 8). These included the use of astrology, since numerous pharmaceutical recipes included directions for admixture and administration according to astrologically propitious times, while the use of astrological images as a form of medical treatment remained a standard practice among university-educated physicians and no learned surgeon would make an incision without first consulting the heavens. Astrology became more, not less, important to medicine during the course of the Renaissance (Hirai 2014, pp. 233-66). However, as fears of necromancy grew in the fifteenth century many theologians attacked both magic and astrology, because as far as opponents of these arts were concerned, both disciplines worked through the secret aid of demons (Kieckhefer 1994, p. 817; Levack 1995, p. 37; Russell 1972, p. 144; Cohn 1975, p. 176). It was for this reason that charges levied against those accused of heresy, or even secular crimes, sometimes combined astrology and necromancy as if they were natural corollaries of one another. For example, in 1441 officials convicted Thomas Southwell and Roger Bollynbroke, masters of Oxford, of using necromancy and astrology on behalf of Eleanor Cobham, duchess of Gloucester, who intended to cause the death of the King. Southwell died in the Tower while Bollynbroke was hanged, drawn, and quartered on 18 Nov. 1441 (Emden 1957, pp. 214-15; Emden 1959, pp. 1734-35). There were undoubtedly political elements involved with this prosecution, but the fact that it was useful to charge these unfortunate academics with astrology and necromancy demonstrates the bad reputation astrology was gaining through association with magic.

\section{Legitimation Gone Wrong}

These growing concerns about magic and associated esoteric arts would become very important to the Dominicans in the 1480s. Thomas Aquinas had been canonized in 1323, but in spite of his fame, Albert had never received this honor. The Dominicans had long taken tremendous pride in Albert's fame, though, and it had been a significant source of legitimation for the order. ${ }^{30}$ Nowhere was that pride greater than in Cologne, where Albert had spent much of his working life, where he had died, and where he was buried. Therefore, in 1483 the city and the university jointly reinterred Albert's remains, accompanied by much pomp and circumstance. In the following year the Dominican's general chapter in Rome formally appealed for his canonization. The friars in the province of Teutonia wrote and sent to press several works glorifying Albert, including the first book-length vitae of their illustrious forebear.

It is in the differences in the two vitae the friars produced about Albert where we can see the ways in which strategies of legitimation can go wrong. In the thirteenth century scholars like Albert had been exuberantly excited about the new Greek, Arabic, and Jewish knowledge available, and for Albert there was no part of that knowledge more exciting than 
astrology. His students, men such as Ulrich of Strasbourg, had gone even further, insisting that Albert was a master of all fields, including those related to astrology that Albert had barely touched upon, like magic, serving as a source of legitimation for the order that could claim this man who was presumably so well versed in such cutting-edge disciplines. By the fifteenth century, however, Albert's reputation as an expert on magic, which was hardly accurate, and astrology, which most definitely was the case, was a problem. As David J. Collins argues, the effort to shave away the negative accretions to Albert's reputation explains the differences between friar Peter of Prussia's (fl.1480s) Legenda venerabilis domini Alberti Magni, published in 1486 or 1487, and Rudolf of Nijmegen's (fl.1490s) strikingly different 1490 vita, Legenda litteralis Alberti Magni (Collins 2010, pp. 7-8). The first work is written in syllogistic scholastic fashion, while the latter employs the tools of the rhetorician, yet both begin by enumerating the slanderous association of Albert with necromancy (Collins 2010, p. 22).

Fortunately for Peter, he had a ready legitimation tool at hand in order to demonstrate that Albert understood the difference between licit and illicit forms of astrology and magic: a manuscript copy of the Speculum was available in Cologne, along with other Albertine works (Speculum mathematicae is a variant title):

A sacred work of his [Albert] on Mathew is held in the monastery of the Preachers of Cologne, written by his own hands. Another volume from his own hands, De naturis animalium, is also held [by the monastery] and similarly [a copy of] the Speculum mathematicae from his own hand. ${ }^{31}$

It was important for Peter to rely on the Speculum, because he was writing this vita in order to fulfill the mandate of his superior in the order, Jakob Sprenger (1438-1496) (Collins 2010, pp. 23-26). Sprenger is best known through his association with the most infamous witch-hunting manual of the later Middle Ages, the Malleus malefacarum. As a member of the Observant movement within the Dominican Order, Sprenger was committed to reforming the Order of Preachers, the Church, and the world around him; central to this goal of reform was Sprenger's desire to extinguish the threat of necromancy, which he believed to be rampant throughout Christendom. Thus, he had to see Albert distanced from this form of apostasy, but it simply was not possible to argue that Albert had no interest in astrology, as his writings on the subject were too extensive. Thus, by authorizing or directing Peter of Prussia to reference the Speculum and make use of its arguments, he could at least demonstrate that Albert's interest in astrology went only so far as the permissible, natural forms of the discipline, rather than veering too near the "impiety of necromancy."32

Unfortunately, Peter's efforts were met with limited success. Rather than achieving Albert's canonization, the Dominicans only gained papal authorization to venerate Albert within their own order and within the diocese of Regensburg, where Albert had once been a bishop. ${ }^{33}$ It would be 1622 before Albert was beatified, and he was not canonized until 1931, when he was also named as a doctor of the church. ${ }^{34}$ It is uncertain how great a role Albert's continuing reputation as a wizard and astrologer played in blocking efforts to have him canonized, but there's no doubt that such associations continued long after his death. As witness, we need look no further than Mary Wollstonecraft Shelley's 1818 Frankenstein, when the author has Doctor Victor von Frankenstein name drop Albert, not once, but three times alongside the Renaissance physician, alchemist, and astrologer, Paracelsus (1493-1541) in order to demonstrate to her readers that the doctor had pursued both magical and scientific studies (Shelley 1869, pp. 31, 33, 36). For that matter, all one needs to do is run a quick web search on Albertus Magnus to find many references to him as an alchemist, ${ }^{35}$ or a wizard and astrologer. ${ }^{36}$ Albert is remembered far more commonly today for things he never did, such as invoke demons or create a talking brazen head, then for the manifold accomplishments he actually made.

What happened to Albert demonstrates the danger of using associations with cuttingedge academic subjects as legitimizing devices. One century's cutting-edge knowledge 
might be another century's superstition, and such associations can be more difficult to unmake than to make. The Dominicans had rolled the dice in the years, decades, and centuries after Albert's death, reinforcing his association with esoteric disciplines, due to the interest these subjects generated and the respect with which many viewed them, even going so far as to spread them through semi-popular forms of discourse such as sermons. They were, after all, building on Albert's very real interest in and support for astrology, as well as his acceptance of the occult properties of stones and the usefulness-and efficacyof image magic. In the end, however, in spite of early successes with this strategy, the image of Albert as a magus likely slowed his canonization considerably.

Funding: This research received no external funding.

Institutional Review Board Statement: Not applicable.

Informed Consent Statement: Not applicable.

Data Availability Statement: Not applicable.

Acknowledgments: Many thanks to Ernesto Livorni of the Department of French and Italian at the University of Wisconsin for steering me in the right direction when I started looking for information about Matteo Corsini. I also owe thanks to Elizabeth Nogan-Rainieri for her assistance in the translation of Corsini's Italian. Conversations with Massimo Rondolino inspired the approach I took in this paper, that of analyzing Albert's reputation and the usefulness of that reputation to the Dominicans. However, the germ of the idea of considering why and how the Albert Legend developed first emerged during a conversation with Thomas Burman in the early 2000s. Finally, I would like to thank the three peer-reviewers who provided comprehensive feedback on this paper, helping me to improve it.

Conflicts of Interest: The author declares no conflict of interest.

\section{Notes}

1 H. Darrell Rutkin coined this term to describe the way in which astrology acted as the link between disciplines such as astronomy, geography, and geometrical optics in their integration into the university curriculum and intellectual mindset of the middle ages. See Rutkin (2002), "Astrology, Natural Philosophy and the History of Science, c. 1250-1700: Studies toward an Interpretation of Giovanni Pico della Mirandola's Disputationes adversus astrologiam divinatricem." Ph.D. diss., Indiana University, p. 62.

2 Mulchahey (1998), "First the Bow Is Bent in Study—“: Dominican Education before 1350 (Toronto: Pontifical Institute of Medieval Studies), pp. 56-57. As Mulchahey notes, the "wording of the prohibition approximates that of the first citation of Gratian in answer" to the question of whether or not ordained clergy should be learned in secular letters. Gratian attributes this prohibition to the Fourth Council of Carthage in 419. By associating the newly written Dominican Constitution with an ordinance of the Patristic period, Dominic was asserting that his organization was part of an ancient tradition.

3 Albert's substantial six-part Summa parisiensi, in which he applied Aristotelian philosophy to an analysis of the Incarnation and Resurrection of Christ, the four coevals (of primal matter, time, the heavens, and the angelic intelligences), human nature, and the nature of the good, is a product of this period, as is his comprehensive commentary on the Sententia. See Aertsen (1996), "Albertus Magnus und die mittelalterliche Philosophie," in Allgemeine Zeitschrift für Philosophie 21: 111-28.

4 Medieval people did not use the term astrology in the way it is used today. Instead, astrologia and astronomia were used interchangeably. Albert most commonly used the term "the science of the judgement of the stars" to refer to what is most commonly meant by the term astrology today. A full discussion of the various understandings of how one might study the heavens to gain knowledge about terrestrial things, the various terms associated with such study, and other considerations can be found in Hendrix (2010), How Albert the Great's Speculum Astronomiae Was Interpreted and Used by Four Centuries of Readers: A Study in Late Medieval Medicine, Astronomy and Astrology (Lewiston: Edwin Mellen), chp. 3.

5 Although Albert almost always identified the author of the Liber de causis as "the philosopher," meaning Aristotle, or simply "the author," in his commentary On the Causes he refers to "a certain David the Jew," and in his Liber de caelo et mundo he refers "to the teaching of Avendaud in the Book of Causes." The translations are from Krisztina Szilágyi who demonstrates that Albert saw David the Jew and Avendaud as the same person. See Szilágyi (2016), "A Fragment of a Book of Physics from the David Kaufmann Genizah Collection (Budapest) and the Identity of Ibn Daud with Avendauth," Aleph: Historical Studies in Science and Judaism 16.1: 10-31, 25-26.

6 Daguillon (1930), Ulrich de Strasbourg, La "Summa de bono." Livre I (Paris: J. Vrin), p. 139.“Vir in omni scientia adeo divinus ... et in magicis expertus." 
7 In his commentary, De anima, Albert wrote, "nos ipsis sumus experti in magicis," in a discussion about Hermeticism. Given the context, Albert was likely referring to having tested Hermeticism or experienced its effects, rather than having had personal knowledge of magic, as nowhere else does he make such a claim. Albert the Great (1980), De anima, Adolphe Borgnet, ed (Paris: Vives), Lib. I, tract. 2, cap. 6, p. 153a.

8 Steenberghen (1947), "Le 'De quindecim problematibus" d'Albert le Grand" in Études d'histoire littéraire et doctrinale de la Scolastique médiévale offertes à Monseigneur Auguste Pelzer. Louvain: Bibliothèque de l'Université/Editions de l’Institut Supérieur de Philosophie, pp. 415-39; Albert the Great (1975). "De quindecim problematibus," in Opera omnia, Bernhard Geyer, ed. Monasterii Westfalorum: Aschendorff, pp. 31-34. The points in question are: "III: Quod voluntas hominis ex necessitate vult et eligit. IV: Quod omnia quae in inferioribus aguntur, subsunt necessitati corporum caelestium. IX: Quod liberum arbitrium est potentia passiva, non activa quod de necessitate movetur ab appetibili. XII: Quod humani actus non reguntur providentia dei." Albert replied with considerable comprehensiveness, concluding with: "Si enim VI liber Primae Philosophiae legitur, facile patet, qualiter ea quae in inferioribus aguntur, superiorum subsunt regimini." For those who do not understand that which is "easily understood" from a reading of "book VI of the first philosophy [Aristotle's metaphysics]"? "omnino pateat eorum ignorantia." Albert, “De quindecim problematibus," p. 36.

9 Lemay (1992), pp. 91-94. I write "incline" because the author of the work, following Albert, argues that the heavens incline people toward certain fates, but do not compel them. Thus, a person could always choose to act against the celestial influence, but since most people never do, predictive astrology is accurate most of the time. Thus, De secretis is not as fatalistic as Lemay seems to believe, if one understands fate to function as Albert does. For a discussion of the way Albert understood "fate," see Hendrix (2008), "Choosing to be Human: Albert the Great on Self Awareness and Celestial Influence" Culture and Cosmos 12.2: $23-41$.

10 The interest in learned magic began to take form as early as the twelfth century, but during the fourteenth through sixteenth centuries this interest began to grow explosively. For a classic study of this phenomenon, see Yates (1964), Giordano Bruno and the Hermetic Tradition (Chicago: University of Chicago Press). For the most up-to-date treatments, see Bailey (2003), Battling Demons: Witchcraft, Heresy, and Reform in the Late Middle Ages (University Park: The Pennsylvania State University Press) and Zambelli (2007), White Magic, Black Magic in the European Renaissance (Leiden: Brill).

11 Kieckhefer (2000), 5th printing. Magic in the Middle Ages (Cambridge: Cambridge University Press), pp. 153-57. The numbers of chantry priests grew considerably in the fourteenth century, and as Kieckhefer points out, such educated men were only "semi-employed," and thus, with a "great deal of time on his hands, he might readily get into trouble. Necromancy was merely one of the forms this might take: not the most common form, perhaps, but not the least interesting." Originally a term that meant the practitioner was discoursing with the dead, necromancy came to include any contact with spirits-including incorporeal demons. See Burnett (1996), “Talismans: magic as science? Necromancy among the Seven Liberal Arts," Magic and Divination in the Middle Ages (Aldershot: Variorum): pp. 1-15, 3-4.

12 Authors such as Agostino Paravicini-Bagliani have engaged in lengthy discussions of what to call this work, but in the 42 manuscript copies I've examined, Speculum astronomiae or some close variant is the most common title, so I will use it from here on out. See Paravicini-Bagliani's (2001), Le Speculum Astronomiae, une énigme? Enquête sur le manuscripts (Sismel: Edizioni del Galluzo), 88-92, and Hendrix (2010), Albert the Great's Speculum Astronomiae, appendix, for a complete discussion of the title.

Kieckhefer (1994), 190; Levack (1995), 2nd edition. The Witch-Hunt in Early Modern Europe (New York: Longman), pp. 7, 38; Shumaker, 111. See also Schwartz (2005), Studies on Astral Magic in Medieval Jewish Thought, translators David Louvish and Batya Stein (Boston: Brill, 2005).

14 d'Ailly (1490), Vigintiloquium de concordantia astronomicae veritatis cum theologia. Venice: Erhardus Ratdolt, f. 3r: "Albertus Magnus perutilem etiam tractatum edidit, in quo verae astronomiae et artis magicae libros per eorum principia et fines distinxit, ut astronomicam veritatem et magicam vanitatem ad invicem sequestraret."

15 I have personally studied 42 of the surviving 58 manuscript copies of the Speculum. Of these, three definitively date to the thirteenth century when the work was written, while eleven date to the fourteenth, seventeen date to the fifteenth, and ten date to the sixteenth century. Only one manuscript copy from my sample group dates to the seventeenth century. See Hendrix (2010), Albert the Great's Speculum Astronomiae, appendix.

16 Albert the Great (1992), the Speculum, p. 222, "Sed isti parti associantur illi libri maledicti necromatici, de imaginibus ... mutuant quasdam observationes astronomicas, ut sic se reddant aliquatenus fide dignos." The translation is my own.

17 Paget Toynbee first noticed this point more than a century ago. See his Toynbee (1895) "Some Unacknowledged Obligations of Dante to Albertus Magnus," Romania 24.95: 399-412. Since then, many scholars have explored the debts Dante owed to Albert, with Etienne Gilson being the most important. See his Gilson (1963) Dante and Philosophy, trans. David Moore (New York: Sheed and Ward).

18 Many thanks to Dr. Ernesto Livorni of the Department of French and Italian at the University of Wisconsin, for steering me in the right direction when I started looking for information about Matteo Corsini.

19 Corsini (1845), Rosaio della vita: Trattato Morale, Filippo-Luigi Polidori, ed. (Florence: Societa Poligrafica Italiana). This is the most recent critical edition of this under-studied work available, representing considerable corrections of the only previous print edition, done in 1736. 
This may indicate that Matteo Corsini had some knowledge of Latin, or he may have been borrowing from someone who had fluency in this language. Another possibility is that he borrowed quotes from available florilegia. Determining Matteo's level of Latin fluency is beyond the scope of this paper, but it seems clear that he wanted readers to perceive him as having some knowledge of and respect for Latin.

21 Corsini (1845), p. 14. The full quote from the Vulgate, Sapientia 7: 29, is "Est enim haec speciosior sole, et super omnem dispositionem stellarum: luci comparata, invenitur prior."

22 Corsini (1845), pp. 15-16. “Come la sapienzia de' essere riverita et onorata infiniti esempli ti potrei dire (3); ma per non dare troppe parole, solo uno notevole ne dirò brevemente. Troviamo che uno Alberto Magno, el quale fu de' Frati Predicatori, venne a tanta perfezione di senno, che per la sua grande sapienzia fe' una statua di metallo a sì fatti corsi di pianeti, e colsela sì di ragione (4), ch' ella favellava: e non fu per arte diabolica nè per negromanzia: però che gli grandi intelletti non si dilettano di cioe, perchè è cosa da perdere 1 ' anima e 'l corpo; che è vietata tale arte dalla fede di Cristo. Onde uno frate chiamando frate Alberto alla sua cella, egli non essendogli (5) la statua rispose. Costui credendo che fosse idolo di mala ragione, la guastò. Tornando frate Alberto, gli disse molto male, e disse che trenta anni ci avea (6) durata fatica, e: Non imparai questa scienza nell' ordine de Frati. El frate dicea: Male ho fatto; perdonami. Come! non ne potrai fare un' altra? Rispose frate Alberto, di qui a trenta migliaia d' anni non se ne potrebbe fare un' altra per lui; però che quello pianeto ha fatto el suo corso; e non ritornerà mai più per infino a detto tempo."The numbers are included in the printed text. My thanks to Dr. Elizabeth Nogan-Ranieri for the translation.

Corsini (1845), p. 159. Eventually the legend emerged that it was Thomas Aquinas (1225-1274) who destroyed Albert's talking head, but I am unsure how that legend began. The earliest reference I can find to it is the rather uncritical assertion by Thomas Warton that "Albertus Magnus, who was also a profound adept at those sciences which were taught by the Arabian schools, is said to have framed a man of brass; which not only answered questions readily and truly, but was so loquacious that Thomas Aquinas ... knocked it in pieces as the disturber of his abstruse speculations." See Warton's (1774) History of English Poetry, vol. 1 (London: J. Dodsely), p. 401.

24 This does not mean that the unknown author of "Es war ein Kung in Frankreich" was a commoner. He may have been wealthy, as was the case of Corsini. He may also have been an academic choosing to write in the vernacular. However, the fact that this was a vernacular-language poem suggests dissemination of Albert's reputation beyond the bounds of the Latinate elite.

d'Ailly (1483), Apologia defensiva astronomiae ad magistrum Johannem cancellerium parisiensem (Louvain: J. de Paderborn), 143v: "Concordemus denique cum Alberto magno doctore sancti Thomae in illo praecipue tractatu suo qui Speculum dicitur, ubi hanc materiam plene utiliterque pertractat." The translation is my own.

26 d'Ailly (1490), Vigintiloquium, f. 3r, "Albertus Magnus perutilem etiam tractatum edidit, in quo vere astronomie et artis magice libros per eorum principia et fines distinxit: ut astronomicam veritatem et magicam vanitatem ab invicem sequestratret." The translation is my own.

Gerson (1962), Tricelogium astrologiae theologizatae, in his Oeuvres Complètes, ed. Mgr. P. Glorieux (Paris: Desclée), caput X, pp. 110-11. "Hanc vero artem [astrology] vel principia eius probare volumus semper extitisse extra et supra totam humanae investigationis facultatem. Ars quippe certa et regularis esse debet; voluntates autem hominum et cogitationes secundum quas deberet talis ars judicativa, capere fundamentum, penitus incertae sunt et variae; ut ergo nulla sit naturaliter ars de eis constantissime fatendum est. Numquid advertimus post Christi Nativitatem (quae utique miraculosa fuit, nec influentiis subjecta,) quanta varietas in conditionibus, moribus et operibus hominum innumerabilium secuta est; cuius attamen Nativitatis conditionem, illi qui principia artis huiusmodi fundare conati sunt, praevidere ut ista exciperent, minime potuerunt."

Gerson (1962), Tricelogium, p. 90, prooemium: "Propterea non est negandum ab astrologia, quam esse sciantiam nobilem et admirabilem primo patriarchae Adam et sequacibus revelatam theologia non abnegat. Verumtamen hanc ancillam suam astrologiam nonnulli tot vanis observationibus, tot impiis erroribus, tot superstitionibus sacrilegis deturpantes maculaverunt, nescientes in ea sobrie sapere et modeste uti, quod apud bonos et graves redita est necdum infamis sed religioni christianorum suisque cultoribus pestilens et nociva."

29 Gerson (1962), Tricelogium, propositio III, p. 107: “Composuit super hac re magnus albertus opusculum quod appelatur Speculum Alberti, narrans quomodo temporibus suis voluerunt aliqui destruere libros Albumasar et quosdam alios. Videtur autem, salvo tanti doctoris honore, quod sicut in exponendis libris philosophicis, praesertim peripateticorum, nimiam curam apposuit, maiorem quam christianum doctorem expediebat, nihil addendo de pietate fidei; ita et in approbatione quorumdam librorum astrologiae, praesertim de imaginibus, de nativitatibus, de sculpturis lapidum, de characteribus, de interrogationibus, nimis ad partem superstitionum ratione carentium declinavit." The translation is my own.

30 Although Collins does not use the language of legitimation, he does discuss the great pride the Dominicans took in Albert's fame. See Collins (2010), “Albertus, Magnus or Magus? Magic, Natural Philosophy, and Religious Reform in the Late Middle Ages," Renaissance Quarterly 63.1: 1-44. I use this source for the information in the rest of this paragraph.

31 Peter of Prussia (1900), Legenda Coloniensis, ed. P. van Loe, “De vita et scriptis B. Alberti Magni,” Analecta Bollandiana, 19: 257-84, 276-77: “In Monasterio Praedictorum Coloniae habetur opus eius [Alberti] solemne Super Matheum propriis manibus suis scriptum. Aliud etiam volumen De naturis animalium de manu sua et Speculum mathematicae similiter de manu sua." The translation is my own. 
Collins (2010), p. 13, quoting from Peter of Prussia. Collins does not, however, note the reasons why it was important that Peter appeal to the Speculum, only that he did so.

33 Collins (2010), p. 32. Collins points out that canonizations were far rarer prior to the nineteenth century than they later became. I'm not sure how much of a consolation this was to the Dominicans of Cologne, though.

Weisheipl (1980), “The Life and Works of St. Albert the Great” in Albertus Magnus and the Sciences (Toronto: Pontifical Institute of Medieval Studies): pp. 13-53.

See http:/ / www.crystalinks.com/mangus.html, accessed on 31 January 2019, where he is described as "student and teacher of alchemy and chemistry, and an alleged magician" and is listed as an alchemist.

36 Christopher Warnock, the self-styled Renaissance astrologer, says that Albert was just one of many who "openly accepted the reality and efficacy of astrology and magic, as sciences that relied on spiritual connection and casuality [sic]." See https: / / www.renaissanceastrology.com/albertusmagnus.html, accessed on 31 January 2019.

\section{References}

Aertsen, Jan. 1996. Albertus Magnus und die mittelalterliche Philosophie. Allgemeine Zeitschrift für Philosophie 21: 111-28.

Albert the Great. 1980. De anima. In Opera Omnia. Edited by Adolphe Borgnet. Paris: Vives.

Albert the Great. 1975. De quindecim problematibus. In Opera Omnia. Edited by Bernhard Geyer. Monasterii Westfalorum: Aschendorff.

Albert the Great. 1992. Speculum Astronomiae. In The Speculum Astronomiae and Its Enigma: Astrology, Theology, and Science in Albertus Magnus and His Contemporaries. Edited by Paola Zambelli. Dordrecht: Kluwer Academic Publishers.

Allen, Don Cameron. 1941. The Star Crossed Renaissance. Durham: Duke University Press.

Bailey, Michael D. 2003. Battling Demons: Witchcraft, Heresy, and Reform in the Late Middle Ages. University Park: The Pennsylvania State University Press.

Bailey, Michael D. 2006. Pope John XXII. In Encyclopedia of Witchcraft: The Western Tradition. Edited by Richard M. Golden. Santa Clara: ABC-CLIO, pp. 597-98.

Bailey, Michael D. 2007. Magic and Superstition in Europe. Lanham: Rowman and Littlefield.

Bianchi, Luca. 2015. Moral Philosophy. In Dante in Context. Edited by Zygmunt G. Barański and Lino Pertile. Cambridge: Cambridge University Press, pp. 159-72.

Black, Robert. 2006. Italian Education: Languages, Syllabuses, Methods. In Language and Cultural Change: Aspects of the Study and Use of Language in the Later Middle Ages and Renaissance. Edited by Lodi Nauta. Leuven: Peeters, pp. 91-112.

Black, Robert. 2007. Education and Society in Florentine Tuscany: Teachers, Pupils and Schools, c. 1250-1500. Leiden: Brill, vol. 1.

Burnett, Charles. 1996. Talismans: Magic as science? Necromancy among the Seven Liberal Arts. In Magic and Divination in the Middle Ages. Aldershot: Variorum.

Carey, Hilary M. 1987. Astrology at the English Court in the Later Middle Ages. In Astrology, Science and Society. Edited by Patrick Curry. Woodbridge: The Boydell Press, pp. 41-56.

Cohen, Simona. 2008. Animals as Disguised Symbols in Renaissance Art. Leiden: Brill.

Cohn, Norman. 1975. Europe's Inner Demons. London: Chatto-Heinemann.

Collins, David J. 2010. Albertus, Magnus or Magus? Magic, Natural Philosophy, and Religious Reform in the Late Middle Ages. Renaissance Quarterly 63: 1-44. [CrossRef] [PubMed]

Copenhaver, Brian P. 1988. Astrology and Magic. In The Cambridge History of Renaissance Philosophy. Cambridge: Cambridge University Press. Corsini, Matteo. 1845. Rosaio della vita: Trattato Morale. Edited by Filippo-Luigi Polidori. Florence: Societa Poligrafica Italiana.

Daguillon, Jeanne. 1930. Ulrich de Strasbourg, La "Summa de bono." Livre I. Paris: J. Vrin.

d'Ailly, Pierre. 1483. Apologia Defensiva Astronomiae ad Magistrum Johannem Cancellerium Parisiensem. Louvain: J. de Paderborn.

d'Ailly, Pierre. 1490. Vigintiloquium de Concordantia Astronomicae Veritatis cum Theologia. Venice: Erhardus Ratdolt.

Davies, Jonathan. 1998. Florence and Its University During the Early Renaissance. Leiden: Brill.

de Libera, Alain. 1990. Albert le Grand et la Philosophie. Paris: J. Vrin.

Emden, Alfred Brotherston. 1957. A Biographical Register of the University of Oxford to AD 1500. Oxford: Oxford University Press, vol. 1. Emden, Alfred Brotherston. 1959. A Biographical Register of the University of Oxford to AD 1500. Oxford: Oxford University Press, vol. 3. Fanger, Claire, and Nicholas Watson, eds. 2015. John of Morigny. In The Flowers of Heavenly Teaching. Toronto: Pontifical institute of Medieval Studies.

Franke, William. 2000. Albert the Great. In The Dante Encyclopedia. Edited by Richard Lansing. London: Routledge, pp. 10-15.

Gerson, Jean. 1962. Tricelogium astrologiae theologizatae. In Oeuvres Complètes. Edited by Palémon Glorieux. Paris: Desclée.

Gilson, Etienne. 1963. Dante and Philosophy. Translated by David Moore. New York: Sheed and Ward.

Glorieux, Palémon. 1951. La vie et les oeuvres de Gerson: Essai chronologique. Archives d'histoire doctrinale et littéraire du Moyen Âge XVIII: 149-92.

Goldthwaite, Richard A. 1980. The Building of Renaissance Florence: An Economic and Social History. Baltimore: The Johns Hopkins University Press.

Hackett, Jeremiah. 2013. Albert the Great and the Speculum astronomiae: The State of the Research at the Beginning of the 21st Century. In A Companion to Albert the Great: Theology, Philosophy, and the Sciences. Edited by Irven Resnick. Leiden: Brill, pp. 437-50. 
Hendrix, Scott E. 2008. Choosing to be Human: Albert the Great on Self Awareness and Celestial Influence. Culture and Cosmos 12: 23-41. [CrossRef]

Hendrix, Scott E. 2010. How Albert the Great's Speculum Astronomiae Was Interpreted and Used by Four Centuries of Readers: A Study in Late Medieval Medicine, Astronomy and Astrology. Lewiston: Edwin Mellen.

Hendrix, Scott E. 2018. Albert the Great, the Speculum astronomiae, and Astrology. Studies in Medieval and Renaissance History 3: 151-90.

Hirai, Hiro. 2014. The New Astral Medicine. In A Companion to Astrology in the Renaissance. Edited by Brendan Dooley. Leiden: Brill, pp. 233-66.

Hissette, Roland. 1977. Enquête sur les 219 articles condamnés à Paris le 7 mars 1277. Louvain: Publications Universitaires.

Kibre, Pearl. 1984. Albertus Magnus on Alchemy. In Studies in Medieval Science: Alchemy, Astrology, Mathematics, and Medicine. London: Hambledon Press.

Kieckhefer, Richard. 1994. The Specific Rationality of Medieval Magic. American Historical Review 99: 813-36. [CrossRef]

Kieckhefer, Richard. 2000. Magic in the Middle Ages, 5th ed. Cambridge: Cambridge University Press.

Lemay, Helen Rodnite. 1992. Women's Secrets: A Translation of Pseudo-Albertus Magnus' De Secretis Mulierum. Albany: State University of New York Press.

Levack, Brian P. 1995. The Witch-Hunt in Early Modern Europ, 2nd ed. New York: Longman.

Marr, Alexander. 2010. Automata. In The Classical Tradition. Edited by Anthony Grafton, Glenn W Most and Salvatore Settis. Cambridge: Belknap Press, pp. 109-10.

McGinn, Bernard. 1998. Visions of the End: Apocalyptic Traditions in the Middle Ages. New York: Columbia University Press.

Mulchahey, M. Michèle. 1998. "First the Bow Is Bent in Study-": Dominican Education before 1350. Toronto: Pontifical Institute of Medieval Studies.

North, John. 1995. The Norton History of Astronomy and Cosmology. New York: W.W. Norton.

Page, Sophie. 2013. Magic in the Cloister: Pious Motives, Illicit Interests, and Occult Approaches to the Medieval Universe. University Park: The Pennsylvania State University Press.

Papi, Anna Benvenuti. 1983. Dizionario Biografico degli Italiani, s.v. "Corsini, Matteo". Rome: Istituto della Enciclopedia italiana, vol. XXIX, pp. 644-47.

Paravicini-Bagliani, Agostino. 2001. Le Speculum Astronomiae, une énigme? Enquête sur le manuscripts. Sismel: Edizioni del Galluzo.

Parker, Betsy. 1980. The Physical Astronomy of Albertus Magnus. In Albertus Magnus and the Sciences. Edited by James A. Weisheipl. Toronto: Pontifical Institute of Mediaeval Studies, pp. 155-85.

Peter of Prussia. 1900. Legenda Coloniensis, ed. Paul van Loe, “De vita et scriptis B. Alberti Magni”. Analecta Bollandiana 19: 257-84. [CrossRef]

Rollo-Koster, Joëlle. 2015. Avignon and Its Papacy, 1309-1417: Popes, Institutions, and Society. Lanham: Rowman and Littlefield.

Rondolino, Massimo A. 2017. Cross-Cultural Perspectives on Hagiographical Strategies: A Comparative Study of the "Standard Lives" of St. Francis and Milarepa. London: Routledge.

Russell, Jeffrey B. 1972. Witchcraft in the Middle Ages. Ithaca: Cornell University Press.

Rutkin, H. Darrell. 2002. 'Astrology, Natural Philosophy and the History of Science, c. 1250-1700: Studies toward an Interpretation of Giovanni Pico della Mirandola's Disputationes adversus astrologiam divinatricem. Ph.D. dissertation, Indiana University, Bloomington, IN, USA.

Schwartz, Dov. 2005. Studies on Astral Magic in Medieval Jewish Thought. Translated by David Louvish, and Batya Stein. Leiden: Brill.

Shelley, Mary Wollstonecraft. 1869. Frankenstein, or, The Modern Prometheus. Boston: Sever, Francis, and Co.

Siraisi, Nancy. 1990. Medieval and Early Renaissance Medicine. Chicago: University of Chicago Press.

Smoller, Laura Ackerman. 1994. History, Prophecy, and the Stars: The Christian Astrology of Pierre D'Ailly, 1350-1420. Princeton: Princeton University Press.

Steenberghen, Ferdinand Van. 1947. "Le ‘De quindecim problematibus" d'Albert le Grand. In Études d'histoire littéraire et doctrinale de la Scolastique médiévale offertes à Monseigneur Auguste Pelzer. Louvain: Bibliothèque de l’Université/Editions de l'Institut Supérieur de Philosophie.

Szilágyi, Krisztina. 2016. A Fragment of a Book of Physics from the David Kaufmann Genizah Collection (Budapest) and the Identity of Ibn Daud with Avendauth. Aleph: Historical Studies in Science and Judaism 16: 10-31. [CrossRef]

Thorndike, Lynn. 1923. History of Magic and Experimental Science. New York: Columbia University Press, vol. 1.

Thorndike, Lynn. 1934. History of Magic and Experimental Science. New York: Columbia University Press, vol. 4.

Thorndike, Lynn. 1955. Further Consideration of the Experimenta, Speculum Astronomiae, and De Secretis Mulierum Ascribed to Albertus Magnus. Speculum 30: 413-43. [CrossRef]

Toynbee, Paget. 1895. Some Unacknowledged Obligations of Dante to Albertus Magnus. Romania 24: 399-412. [CrossRef]

Warton, Thomas. 1774. History of English Poetry. London: J. Dodsely, vol. 1.

Weill-Parot, Nicolas. 2002. Les "images astrologiques" au moyen âge et à la renaissance: Spéculations intellectuelles et pratiques magiques (XIIe-XVe siècle). Paris: Champion.

Weinryb, Ittai. 2016. The Bronze Object in the Middle Ages. Cambridge: Cambridge University Press.

Weisheipl, James A. 1980. The Life and Works of St. Albert the Great. In Albertus Magnus and the Sciences. Toronto: Pontifical Institute of Medieval Studies.

Yates, Frances. 1964. Giordano Bruno and the Hermetic Tradition. Chicago: University of Chicago Press.

Zambelli, Paola. 2007. White Magic, Black Magic in the European Renaissance. Leiden: Brill. 